\title{
BŁĘKITNE POWIDOKI, BŁĘKITNE PRZECZUCIA. ZAMIAST WPROWADZENIA
}

DOI: $10.19195 / 0860-116 X .37 .1$

„Boże! kto Ciebie nie czuł w Ukrainy/ Błękitnych polach, gdzie tak smutno duszy (...)"1. Pola nie bywają błękitne, lecz przecież wierzymy Słowackiemu na słowo, że na Ukrainie rzeczy mają się inaczej — że ziemia ma lub przynajmniej miewa tam kolor nieba, zatem właśnie błękitny, tak iż wszelki horyzont bywa od czasu do czasu niwelowany i stajemy oko w oko z tym wszystkim, co jest w nas inne „nadprzyrodzone, ponadczasowe, nierzeczywiste”. Ukraina jest dla Polaka okazją do rozumienia, że polska wyobraźnia symboliczna — fantazmatyczna nieświadomość Ducha - jest nieodwracalnie uwikłana w tajemniczy świat Wschodu i że nie tylko sarmatyzm, ale nawet polski romantyzm to po prostu warianty „łacińskiego orientalizmu", potężne wyrazy drzemiącej w nas geokulturowej sprzeczności. Nie sposób sobie wyobrazić - zresztą i słuchać hadko — że postępy mieszczańskiej mentalności zamienią nas w końcu w Holendrów Wschodu albo Czechów Północy. Inna Rzeczpospolita nie jest możliwa, ponieważ nosimy pod powiekami obraz nierzeczywistych, mistycznych, błękitnych pól Ukrainy. „Moralne zwłoki szlachcica kresowego", o których pisał Paweł Jasienica w nieszczęsnej recenzji Drogi donikąd, zapadają się w nas coraz głębiej, ale — zgodnie z archeologiczną naturą psychiki, którą odkrył i wyzyskał Freud - nigdy nie znikną, tajemnie reprodukując wieczną niezupełność naszej zachodniej orientacji.

Po drugiej wojnie światowej, mocą osławionego ołówka Stalina, Polska została przesunięta na zachód. Nie jest jasne, czy stało się to, co stać się musiało (jak sądził na przykład Jerzy Stempowski), czy przeciwnie — złamana została kluczowa oś polskiej duszy, a ona sama runęła w przepaść. Józef Wittlin wyznawał rozpaczliwie:

1 J. Słowacki, Beniowski, [w:] J. Słowacki, Dzieła, red. J. Krzyżanowski, t. 3: Poematy. Beniowski, Wrocław 1959, s. 116. 
„Nie mogę zrezygnować ze Lwowa, bo Lwów nie chce zrezygnować z rudymentarnych składników mego życia psychicznego. A tego żadne «koncepcje» polityków nie zmienią" ". Sześćset lat polskiej historii usunięto na prawie pół wieku z polskiego życia publicznego, pomijając co prawda piśmiennictwo emigracyjne, a także — po 1956 roku - koncesjonowany dyskurs historyczny, nieco tylko zawężony literacki kanon czy też cokolwiek zamglone w swojej wymowie i zdecydowanie nieliczne filmowe wycieczki na Wschód ${ }^{3}$. Przez całe peerelowskie półwiecze coś się tliło w polskiej świadomości, ale niewyraźnie, aż w końcu, po roku 1989, okazało się, że to coś w nas pękło i, wbrew litewskim na przykład obawom, zaistniał czy raczej ujawnił się w polskim społeczeństwie - jak też w polskiej polityce - szeroki i trwały konsensus co do bezzasadności jakichkolwiek roszczeń terytorialnych wobec państw „obszaru ULB”, tj. Ukrainy, Litwy i Białorusi. Wielka wojna o Kresy — jak konstatował już w początkach sierpnia 1945 roku ranny partyzant Łupaszki Leon Lech Beynar, czyli późniejszy Paweł Jasienica — została ostatecznie przegrana. Nie tylko dlatego, że ćwierć wieku wcześniej umarł w Polsce „duch przygody”4, ale też z przyczyn ogólniejszych. Nowoczesny zachodni nacjonalizm, zaszczepiony po 1863 roku zarówno Polakom, jak i Litwinom, a zwłaszcza Ukraińcom (szczególnie tym ,piemonckim”, czyli galicyjskim) okazał się zabójczy dla Rzeczypospolitej jako idei. Równie nowoczesny i takoż zachodni socjalizm, ujawniając anachronizm stojącej za tą ideą konstrukcji społecznej, dokonał dzieła. Coś w nas wszystkich, jako się rzekło, pękło. Program federacyjny — wobec Ukrainy konfederacyjny Piłsudskiego nie trafił na podatny grunt ani u nas, ani u nich. Demokratyczna tendencja XIX-wiecznej polityki polskiej (Pogoń i Archanioł obok Orła na sztandarach powstańców styczniowych) zdegradowała się — mimo literacko doskonałych protestów młodego Józefa Mackiewicza i innych — do postaci nowoczesnej, czyli fatalnej polityki mniejszościowej Drugiej Rzeczypospolitej.

Idea polskiego narodu politycznego, ponadetnicznego, zaatakowana wirusem szeroko pojętego modernizmu, okazała się słaba, a w ukrytym życiu duchowym Polaków doby PRL-u słabość ta stała się nagle oczywista. Wcześnie dostrzegło to środowisko paryskiej „Kultury”, najbystrzej pod piórem Juliusza Mieroszewskiego, ale przecież nie tylko ono. Powrót - a właściwie przyjazd - Stanisława Cata-Mackiewicza do nowej Polski w 1956 roku był niewątpliwym i wymownym symbolem politycznego bankructwa wielowiekowego sentymentu. Znaczna część późniejszej eseistyki historycznej niegdysiejszego redaktora wileńskiego „Słowa” — w swoim cudownym, z ducha szekspirowskim pomieszaniu akcentów tragicznych i komicz-

${ }^{2}$ Za: R. Habielski, Realizm, wizje i sny romantyków. O pisarstwie Juliusza Mieroszewskiego, [w:] J. Mieroszewski, Finat klasycznej Europy, oprac. R. Habielski, Lublin 1997, s. 48.

3 W rodzaju ekranizacji drugiej i trzeciej części Sienkiewiczowskiej Trylogii oraz obrazów bardziej kameralnych, takich jak Matka Joanna od Aniołów, Lokis czy Znachor.

4 Tak Michał K. Pawlikowski, komentując poniekąd kapitulancki - w stosunku do federacyjnych planów Piłsudskiego (a tym bardziej zamierzeń Petlury) — pokój ryski. 
nych — jest wyrazem zmagania się w tym arcypolskim umyśle porażającego uczucia i zimnej pragmatyki, polskiego racjonalizmu i litewskiej metafizyki. Co dalej z Polską? Co dalej z Ukrainą i Litwą? „Ale dziś już jest za późno, aby odnawiać te spory" ${ }^{\prime}$. Czy aby?

Po pomarańczowej rewolucji i zwłaszcza Majdanie zda się, acz trudno to wypowiedzieć precyzyjnie, że jakkolwiek wciąż jest w istocie za późno, to jest też zarazem — być może, być może... - za wcześnie. Za wcześnie mianowicie, by traktować wytworzone na rozległym obszarze Pierwszej Rzeczypospolitej kulturowe struktury i możliwości w kategoriach wyłącznie historycznych, na zasadzie, by tak rzec, gloria victis. Nie ma oczywiście powrotu do rojeń po prostu imperialnych — nie trzeba sięgać do Daniela Beauvois, by wiedzieć lub co najmniej przeczuwać, że wieki polskiej dominacji na Ukrainie, najpierw politycznej, potem ekonomicznej i ogólniej cywilizacyjnej, nie sprowadzają się bynajmniej, zwłaszcza z perspektywy samych Ukraińców, do wielokulturowej sielanki. Ten model zdezaktualizował się do imentu. Niemniej geopolityczna oś Gdańsk-Odessa i jej mniejsze, geokulturowe postaci (Warszawa-Kijów, Kraków-Lwów) kuszą możliwościami rozszerzenia zakresu i charakteru modernizacyjnej metamorfozy Europy Wschodniej. Wydaje się przy tym, że i Ukraina, i Polska mogłyby na tym dużo zyskać. Podobnie obie kultury. Wyłaniająca się przed nami wspólna perspektywa pozostaje z wielu powodów odległa i abstrakcyjna, niemniej nie sposób nie odczuć jej błękitnawego powabu.

Walter Gropius, założyciel słynnego Bauhausu, zauważa, że ,zaprojektowanie wielkiego budynku różni się od wymyślenia prostego krzesła wyłącznie poziomem zaawansowania, nie zaś fundamentalnymi zasadami"'. Wbrew temu, co mogłoby się wydawać, abstrakcyjna perspektywa ukraińsko-polskiego zbliżenia, o której wyżej piszę, nie ma charakteru wyłącznie czy przede wszystkim politycznego. Inaczej niż Wołodymyr Wjatrowycz ${ }^{7}$ - autor tyleż w Polsce znanej, co nader kontrowersyjnej Wojny polsko-ukraińskiej 1942-1947 — nie uznaję porozumienia bez pojednania za wystarczający fundament naszego sąsiedztwa, mimo że historia naszej części świata od jakichś dwóch lat poważnie przyspiesza i porozumienie takie może okazać się ostatecznie pilniejsze niż pojednanie, tak iż będzie można powtórzyć za Janem Kieniewiczem: „Albo otworzymy nowy rozdział dziejów, w którym znajdziemy niektóre znane nam warianty, albo będziemy czekać na powtórzenie dziejowych calamitates" $"$.

Zacznijmy wszakże, tymczasem, od zaprojektowania Gropiusowego „krzesła”, koncepcyjnego prototypu możliwego gmachu wschodnioeuropejskiej przyszłości.

5 S. Cat-Mackiewicz, Pisma wybrane, oprac. J. Sadkiewicz, t. 8: Herezje i prawdy, Kraków 2012, s. 198.

6 W. Gropius, Petnia architektury, przeł. K. Kopczyńska, Kraków 2014, s. 39-40.

7 W. Wjatrowycz, Porozumienie bez pojednania, rozmawia M. Wojnar, „Nowa Europa Wschodnia" 2016, nr 1, s. 128.

8 J. Kieniewicz, Spotkania Wschodu, Gdańsk 1999, s. 237. 
Na początku niniejszego szkicu zrekonstruowałem w trzech słowach obecny w polskiej świadomości i nieświadomości zbiorowej „ukraiński sentyment”. Świadomie natomiast zrezygnowałem z rekonstruowania - silniejszego bodaj, gdy idzie o społeczny zasięg - „ukraińskiego resentymentu”, co nie oznacza, bym uznawał kwestię takiej rekonstrukcji za błahą czy tym bardziej szkodliwą. Przeciwnie. Na film Wojciecha Smarzowskiego o Wołyniu czekam z niepokojem, ale też z nadzieją, że moc filmowego obrazu pozwoli przenieść dyskusję o polsko-ukraińskim sąsiedztwie na forum najogólniejsze, na którym spotykają się — w sposób widzialny i niewidzialny — nie dziesiątki ludzi, ale tysiące, co najmniej tysiące. $\mathrm{Z}$ podobną nadzieją, i rzecz jasna podobnym niepokojem, czekałbym na ukraiński filmowy portret polskiego dworu czy też akcji „Wisła”, o zaszłościach XVII-wiecznych nie wspominając. Nie dlatego, że chciałbym wyrzucić spod powiek błękitne pola, tylko raczej po to, by je tam właśnie zachować. „Granice Europy jako koncepcji lub wyobrażenia ustalają panujący czy rządzący, natomiast wymiar przestrzenny cywilizacji europejskiej nosimy w sobie. Przestrzenie oznaczone aksjologicznie zmieniają się wolniej od politycznych i wyraźniej są związane z decyzjami ludzi"9.

Pawel Kuligowski

9 J. Kieniewicz, Ekspansja, kolonializm, cywilizacja, Warszawa 2008, s. 267. 